\title{
EMBASSY OF PRINCE GRIGORY KONSTANTINOVICH VOLKONSKY TO THE CRIMEA IN 1614-1615
}

\author{
Alexander V. Vinogradov \\ Institute of Russian History, RAS, Moscow, Russian Federation
}

\begin{abstract}
Introduction. The author examines the insufficiently studied period of diplomatic communications of the Moscow Tsardom and the Crimean Khanate after Mikhail Fedorovich Romanov's enthronement, which led to establishing relatively peaceful mutual relations between them at the final stage of military and political confrontation of Russia with the Polish-Lithuanian Commonwealth and the Swedish Crown. Materials. The paper reveals the circumstances of establishing contractual relations between Moscow and Bakhchysarai on the basis of unpublished sources. The information from the columns of 1613-1614 about the stay of the embassy of A. Lodyzhensky and P. Danilov in the Crimea from autumn of 1613 to July 1614, the preparation and holding of the embassy congress and exchange of ambassadors at Livny in August 1614, the stay of the embassy of Prince G.K. Volkonsky and P. Ovdokimov in the Crimea in August 1614 - June 1615, the stay of Magmet Chelebi's embassy in Moscow in September 1614 - March 1615 and, finally, the embassy exchange under Valuyki in July 1615 form a single set of documents that let us trace the course of diplomatic relations between the Moscow Tsardom and the Crimean Khanate in 1613-1615. The decisive stage in difficult and tense diplomatic negotiations of the parties in this period, in our opinion, is the stay of the embassy of Prince Grigory Konstantinovich Volkonsky and clerk Peter Ovdokimov in the Crimea. Results. This article shows the role of relations with the Crimea in general foreign policy of the government of Tsar Mikhail Fedorovich and in the restoration of military and political control over the Lower Volga Region territory.

Key words: the Time of Troubles, the Crimean Khanate, the Great Nogay Horde, the Moscow Tsardom, the Polish-Lithuanian Commonwealth, Khan Dzhanibek-Girey, ambassador Prince Grigory Konstantinovich Volkonsky, Beg Akhmed-pasha Yashlavsky - "prince Suleshev".

Citation. Vinogradov A.V. Embassy of Prince Grigory Konstantinovich Volkonsky to the Crimea in 1614-1615. Vestnik Volgogradskogo gosudarstvennogo universiteta. Seriya 4, Istoriya. Regionovedenie. Mezhdunarodnye otnosheniya [Science Journal of Volgograd State University. History. Area Studies. International Relations], 2019, vol. 24, no. 2, pp. 158-174. (in Russian). DOI: https://doi.org/10.15688/jvolsu4.2019.2.14
\end{abstract}

\section{ПОСОЛЬСТВО КНЯЗЯ ГРИГОРИЯ КОНСТАНТИНОВИЧА ВОЛКОНСКОГО В КРЫМ 1614-1615 ГОДОВ}

\author{
Александр Вадимович Виноградов \\ Институт российской истории РАН, г. Москва, Российская Федерация
}

Аннотация. Автор рассматривает ранее малоизученный период дипломатических связей Московского царства и Крымского ханства после воцарения Михаила Федоровича Романова, приведший к установлению относительно мирных взаимоотношений между ними на заключительном этапе военно-политического противостояния России с Речью Посполитой и Шведской Короной. На основе неопубликованных источников выявлены обстоятельства установления договорных отношений между Москвой и Бахчисараем. Показана роль отношений с Крымом в общей внешнеполитической линии правительства царя Михаила Федоровича и в восстановлении военно-политического контроля над территорией Нижнего Поволжья. 
Ключевые слова: Смута, Крымское ханство, Большая Ногайская Орда, Московское царство, Речь Посполитая, хан Джанибек-Гирей, посол князь Григорий Константинович Волконский, бек Ахмед-паша Яшлавский - «князь Сулешев».

Цитирование. Виноградов А. В. Посольство князя Григория Константиновича Волконского в Крым 1614 1615 годов // Вестник Волгоградского государственного университета. Серия 4, История. Регионоведение. Международные отношения. - 2019. - Т. 24, № 2. - C. 158-174. - DOI: https://doi.org/10.15688/jvolsu4.2019.2.14

Введение. Период 1613-1618 гг. является одним из самых важных, но до сих пор недостаточно исследованных в истории внешней политики России.

Избрание Михаила Федоровича вернуло Московское государство и Речь Посполитую к состоянию войны. Возобновлению крупномасштабных военных действий со стороны Речи Посполитой весной и летом 1613 г. мешало отсутствие финансовых ресурсов и разногласия в правящих кругах. Это давало надежду правительству царя Федора Ивановича на заключение перемирия с Речью Посполитой, что являлось целью миссии Дениса Оладьина. Результаты посольства показали, что основой для переговоров о заключении перемирия может быть только согласие московской стороны на переход захваченных к тому времени польско-литовскими войсками территорий России к Речи Посполитой. К тому же польско-литовская сторона настаивала на сохранении в силе августовского договора 1610 г. и не признавала «легитимность» избрания Михаила Федоровича [4, с. 50-53]. Исходя из бесперспективности заключения перемирия, московскими властями было принято решение о развертывании военных действий на западных рубежах. К сентябрю 1613 г. началась блокада Смоленска. Одновременно военная активность нового правительства была нацелена и на Новгородскую землю, где предстояла затяжная борьба со шведами. Значительные силы были брошены на преследование уходившего в Астрахань отряда И. Заруцкого [8, с. 161, 174, 193].

Для правительства «новоизбранного царя» Михаила Федоровича Романова жизненно необходимо было найти союзников среди ведущих держав, или, по крайней мере, добиться их дружественного нейтралитета в продолжавшемся противостоянии с Речью Посполитой и Шведской Короной. Именно эту цель преследовала предпринятая в июне 1613 г. беспримерная дипломатическая акция по одновременному отправлению посольств в Иран, Турцию, Империю, Англию и Данию [5, c. $105-106 ; 7$, с. $214 ; 10$, с. 333 ]. В этой ситуации особое место в дипломатических маневpax Москвы занимал вопрос о соглашении с Крымским ханством. Стремление направить набеги крымцев в сторону Польско-Литовского государства в периоды открытого военного противостояния с ним являлось неотъемлемой частью московской дипломатии на протяжении всего XVI века. Весьма остро перед московскими властями стояла проблема борьбы с татарскими нападениями на территорию России. Правда, они осуществлялись в основном мурзами Большой Ногайской Орды и Малой Ногайской Орды, однако в них участвовали и отдельные мурзы «Арсланаева улуса», подданные крымского хана [14, c. 75-77].

Серьезную угрозу представляло наметившееся «взаимопонимание» водворившегося в Астрахани с Мариной Мнишек и ее «воренком» И. Заруцкого с бием Большой Ногайской Орды Иштереком. Москва уже с весны 1613 г. предпринимала попытки наладить отношения с бием Иштереком с тем, чтобы вернуть его в орбиту своего влияния, но они не принесли успеха $[17$, с. $6 ; 18$, с. 396].

Взаимоотношения с вышедшей в начале Смуты из-под политического контроля московских царей Большой Ногайской Ордой должны были осуществляться в едином комплексе налаживания отношений с Крымом: Крымские ханы всегда видели в Больших Ногаях потенциальную угрозу своему господству в причерноморской степной зоне. Всплески военной активности «заволжских ногаев» дестабилизировали ситуацию в подвластном крымским ханам «Арсланаевом улусе». Для Бахчисарая также существовала проблема сохранения своего контроля над Малой Ногайской Ордой («Казыевом улусом»). Все это усугублялось для крымского хана Джанибек-Гирея наличием претендента на престол в лице Шагин-Гирея, 
стремившегося найти в лице всех ногайских мурз опору для борьбы за овладение бахчисарайским престолом. К тому же все более отчетливо проявлялись связи Шагин-Гирея с Сефевидским Ираном - основным противником Порты [6, с. 397; 14, с. 85-86].

Между тем Оттоманская Порта вступала в затяжной военный конфликт с Речью Посполитой, куда неизбежно должен был быть вовлечен Крым [20, с. 60-61]. Ситуация осложнялась участившимися нападениями запорожских «черкасов» на побережье Крыма и на османские владения в Причерноморье.

В этих условиях и сам хан ДжанибекГирей, и лояльные ему представители династии Гиреев - калга [первый наследник престола Девлет-Гирей и нурадин (второй наследник престола) Азамат-Ширей], и большая часть крымской знати весьма серьезно отнеслись к изменению поздней осенью 1612 г. ситуации в Московском царстве, тем более что первые контакты с Крымом руководства Второго ополчения уже имели место [11, с. 271].

«Крымское направление» внешней политики правительства царя Михаила Федоровича, являвшееся прямым продолжением внешнеполитической деятельности «ярославского правительства», становилось ключевым. Неслучайно, что самая первая дипломатическая миссия нового правительства была отправлена уже в марте 1613 г. именно в Крым одновременно, а возможно, и ранее с отправлением гонцов в Речь Посполитую и к бию Большой Ногайской Орды Иштереку [10, c. 333].

Методы и материалы. Значение установления «ссылок» с Крымским ханством для хода военно-дипломатического противостояния России с Речью Посполитой и Швецией признавалось еще в дореволюционной отечественной историографии. Однако только А.А. Сергеев обратился к исследованию собственно хода дипломатических переговоров между Москвой и Бахчисараем после избрания царя Михаила Федоровича в связи с юбилеем этого исторического события в 1913 г. $[15$, c. 7-19].

Проблеме взаимоотношений России с Крымом после 1613 г. посвящен значительный раздел фундаментального труда А.А. Новосельского «Борьба Московского государ- ства с татарами в первой половине XVII века». Многие выводы ученого об общем характере «ссылок» с Крымом сохраняют актуальность, однако нуждаются в серьезной корректировке, что показано в ряде работ современных исследователей «внешнеполитической истории» Смуты, в первую очередь Д.В. Лисейцева [11, с. $238-282 ; 12$, с. 422-423; 13, с. 69-77].

Д.В. Лисейцев реконструировал обмен посольскими миссиями между Москвой и Бахчисараем за все время Смуты (с 1604 по 1619 г.) в рамках общего обзора деятельности Посольского приказа за этот период [10, c. 327-342]. Большое значение имеет проведенный Д.В. Лисейцевым анализ сохранившихся материалов фонда № 123 «Сношения России с Крымом» Российского государственного архива древних актов (РГАДА). Из выявленных Д.В. Лисейцевым столбцов за период с 1613 по 1615 г. сохранилось 6 дел (общее количество дел с 1604 г. - 51). За 1613 г. полностью утрачены все материалы посланников В. Пургасова и Д. Радцева, но в столбцах за 1613 г. сохранилась документация посольства А. Лодыженского и П. Данилова ${ }^{1}$.

Документация посольства А. Лодыженского и П. Данилова, включавшая в себя «наказную память», несколько грамот на имя государя Михаила Федоровича и «статейный список» посольства, была опубликована в полном объеме А.А. Сергеевым в 1913 г. в составе 50-го тома Известий Таврической Архивной Ученой Комиссии (ИТУАК) [16, с. 20 56]. Отметим, что это единственная до настоящего времени публикация посольской документации из состава фонда № 123 РГАДА эпохи Смуты. Посольская документация по связям с Крымом 1614-1615 гг. в столбцах за 1614 г. сохранилась практически в полном объеме. «Наказная память», данная разменным послам князьям Г.П. Ромодановскому и А.Ф. Гагарину и подьячему С. Самсонову для проведения посольского съезда и размена под Ливнами, также как и представленный ими «статейный список», детально отражающий ход посольского съезда и размена под Ливнами в августе 1614 г., содержатся в одном деле за 1614 год ${ }^{2}$. Одно дело представляет собой документацию по отправлению в Крым посольства князя Г.К. Волконского и дьяка П. Овдокимова ${ }^{3}$. «Отписки» посольства кня- 
зя Г.К. Волконского и дьяка П. Овдокимова, отражающие помимо описания их пребывания в Крыму ход посольского съезда и размена под Ливнами в августе 1614 г. и посольского размена под Валуйками в июле 1615 г., содержатся в двух делах за 1614 год ${ }^{4}$. За 1614 г. в столбцах сохранились также материалы по приему прибывшего в Москву 12 сентября 1614 г. после размена под Ливнами посольства Мустафы-мурзы и гонца Мухаммеда Челибея (Магмета Челеби) ${ }^{5}$. Как отметил Д.В. Лисейцев, сохранившиеся сведения столбцов за 1613-1614 гг. позволяют практически полностью восполнить состав одной из утраченных при пожаре 1626 г. крымских посольских книг, в которой «были объединены материалы об отправлении к крымскому хану А. Лодыженского и П. Данилова в 1613 г., Г.К. Волконского и П. Овдокимова в 1614 г. на «посольский размен» [11, с. 243-244]. Кроме того, как отмечает Д.В. Лисейцев, «помимо столбцов во второй описи фонда 123 отмечены две шертные грамоты крымских ханов 1614-1615 гг. ${ }^{6}$, представляющие собой поздние выписки из столбцов» [11, с. 243].

Таким образом, отраженные в столбцах 1613-1614 гг. пребывание в Крыму посольства А. Лодыженского и П. Данилова с осени 1613 по июль 1614 г., подготовка и проведение посольского съезда и размена под Ливнами в августе 1614 г., пребывание в Крыму посольства князя Г.К. Волконского и П. Овдокимова в августе 1614 г. - июне 1615, а в Москве посольства Магмета Челеби в сентябре 1614 г. - марте 1615 г. и, наконец, проведение посольского размена под Валуйками в июле 1615 г. образуют единый комплекс документов, которые позволяют проследить ход дипломатических отношений между Московским царством и Крымским ханством в 16131615 годах. Решающим этапом в тяжелых и напряженных дипломатических переговорах сторон этого периода, на наш взгляд, является пребывание в Крыму посольства князя Григория Константиновича Волконского и дьяка Петра Овдокимова.

Анализ. В руководстве Посольского приказа, возглавляемого Петром Третьяковым, полагали, что в налаживании союзных отношений с Бахчисараем имеется хорошая перспектива. Многолетний опыт показывал, что усиление Польско-Литовского государства в ущерб Московскому не отвечает интересам Крыма, что проявилось на заключительном этапе Ливонской войны. Действительно, итоги миссии В. Пургасова, отправленного в Крым в марте 1613 г. и вернувшегося уже в июне того же 1613 г. вместе с большой группой крымских гонцов во главе с Аллаш Богатыром, демонстрировали явное намерение крымской стороны к восстановлению как минимум добрососедских отношений. Послания хана Джанибек-Гирея, адресованные царю Михаилу Федоровичу, выражали намерения установления «мира, дружбы и братской любви». При этом дипломатические связи Москвы с Портой к этому времени еще только восстанавливались $[17$, с. 4-5]. Как отметил Б.Н. Флоря, «крымская знать раньше, чем османские политики, поняла, что события 1612 г. в России означают восстановление Русского государства и возобновление традиционного для Восточной Европы конфликта и вернулась к своей тактике поддержки более слабой стороны» [20, с. 59]. Многие признаки указывали на скорый конфликт Порты с Речью Посполитой из Молдавского княжества, куда неизбежно будет вовлечен Крым.

В Москве не без оснований полагали, что восстановление «ссылок» с Бахчисараем будет облегчено рядом факторов: в Крыму попрежнему пользовался влиянием клан наследственных московских «амиатов» Яшлавских $[2$, с. $26-73 ; 3$, с. $25-41 ; 14$, с. 19-20]. Его с 1591 г. возглавлял престарелый Ахмед-паша Яшлавский - «князь Сулешев», «ближний человек» и «карачей» четырех крымских ханов: Гази-Гирея II (1588-1596, 1597-1607), Тохтамыш-Кирея (1607-1608), Селамет-Гирея (1608-1610) и, наконец, Джанибек-Гирея (1610 1623).

Своеобразие ситуации заключалось и в том, что племянники Ахмед-паши - сыновья его брата Янши-мурзы б. Сулеша - бывшего крымского посла в Москве, оставшегося там в период «ссоры великой в крымском юрте», именно после 1613 г. упрочили свои позиции в составе государева двора царя Михаила Федоровича [1, с. 145-146]. Эти родственные связи рассчитывали использовать в Москве. Не случайно в «наказной памяти» послам князю Г.К. Волконскому и П. Овдокимову пред- 
писывалось упомянуть ратные подвиги воеводы князя Юрия Яншеевича Сулешева ${ }^{7}$. Рассчитывали в Москве и на лояльность главы клана Мансуров Богатыр-Гирея «князя Дивеева», который в 1609 г. заключил соглашение (шертовал) с эмиссаром царя Василия Шуйского - боярином князем И.М. Воротынским - о военной помощи крымцев против «воров» [11, с. 265]. Хотя соглашение было сорвано крымской стороной, о принесении шерти Богатыр-Гирею московские дипломаты в дальнейшем «напомнили» ${ }^{8}$. Кроме того, в Крыму находились братья князья Петр и Александр Араслановичи Урусувы - Уракмурза б. Джан-Арслан и Зурбек-мурза б. Джан-Арслан. Князь Петр, знаменитый убийца Лжедмитрия II, по слухам, пользовался расположением хана Джанибек-Гирея, а князь Александр одно время находился с отцом Джан-Арсланом в Астрахани [19, с. 337]. В Москве полагали, что даже если братьев не удастся склонить к возвращению в Московское царство, они могут оказать содействие в установлении «доброго дела» между Москвой и Крымом. К тому же их отец ДжанАрслан-мурза б. Урус являлся «перспективной фигурой» в налаживании отношений Москвы с бием Большой Ногайской Орды Иштереком. Вокруг находившегося в руках у И. Заруцкого в Астрахани Джан-Арслана именно в это время начиналась большая дипломатическая игра: он рассматривался всеми «заинтересованными сторонами» как лицо, которое сможет в случае необходимости сменить Иштерека в качестве бия Большой Ногайской Орды [18, с. 397].

В Москве прекрасно осознавали, что нападения на практически беззащитные московские «украйны» совершались мурзами Больших и Малых ногаев при участии подвластных крымским ханам мурз «Дивеева улуса», но не стремились «заострить» этот вопрос. Сам крымский хан Джанибек-Гирей и его «ближние люди» при переговорах со всеми московскими дипломатами всегда говорили, что эти нападения осуществлялись «воровством» без их ведома. Недовольство в Крыму активностью ногаев было вполне объяснимо. «Самоуправство» ногайских мурз затрагивало их интересы. Посольство князя Г.К. Волконского и П. Овдокимова, везшее «поминки» и «запросные деньги», два дня в августе 1614 г. пережидало в Валуйках отход ногайцев из очередного успешного набега.

Для осуществления дипломатических «ссылок» с Крымом в распоряжении правительства Михаила Федоровича имелись опытные дипломаты: князь Григорий Константинович Волконский, успешно исполнивший посольство в Крым в 1601-1602 гг., и Амброзий Лодыженский, - посольство в 1598 году. В организации «ссылок» с Крымом имелись значительные «наработки» уже в период непосредственно Смутного времени. В частности, еще до освобождения Москвы руководство Первого ополчения сделало попытку установления «ссылок» с Крымом.

Однако в Посольском приказе прекрасно понимали все сложности установления союзных или, по крайней мере, добрососедских отношений с Крымом, о чем свидетельствуют инструкции, данные дипломатическим представителям, направляемым в Крым: «наказная память» посольству А. Лодыженского и подьячего П. Данилова, а также «наказная память» посольству князя Г.К. Волконского и дьяка П. Овдокимова. Прежде всего военный и политический престиж Москвы в глазах крымского хана «царевичей» Гиреев и знати упал в период Смуты. Военный потенциал Москвы был существенно подорван, система обороны южных рубежей Московского государства пришла в упадок. Крайне негативным фактором являлось пребывание «царицы» Марины Мнишек с ее «воренком» в Астрахани. Нижнее Поволжье традиционно рассматривалось крымскими ханами как зона их интересов. От претензий на «Астраханскию юрт», а также и на «Казанский юрт», хан ГазиГирей II отказался только в 1591-1593 гг. во время секретных переговоров своего эмиссара Ямгурчея аталыка с доверенным лицом Б.Ф. Годунова переводчиком Посольского приказа С. Степановым, затем с Посольским дьяком А.Я. Щелкаловым и, наконец, непосредственно с самим Борисом Федоровичем. При этом «публично» крымские ханы от претензий на Казань и Астрахань никогда не отказывались. Поэтому факт принадлежности Астрахани (а в случае необходимости, и Казани) Московскому царству не должен был ни при каких обстоятельствах быть оспаривае- 
мым крымской стороной - в наказной памяти А. Лодыженскому и П. Данилову «Казань и Астрохань за государями нашими из давних лет, а бывали на казанском юрте цари из рук государей наших» [16, с. 38]. В «наказной памяти» посольству Г.К. Волконского - П. Овдокимова говорилось: «Казань и Астрохань исконно отчина великих государей наших царей и великих князей Российских» 9 .

Существовало и еще несколько негативных факторов. Последнее московско-крымское «докончание» было заключено в ходе переговоров посольства Г.К. Волконского в 1602 г., но долго не было ратифицировано Борисом Годуновым. Его «крестоцелование» состоялось буквально накануне смерти. Соглашение, по существу предварительное «докончание» 1609 г., заключенное князем И.М. Воротынским от имени царя Василия Шуйского с Богатыр-Гиреем «Дивеевым», было сорвано уже крымской стороной. Правда, все «докончания» Крыма с Москвой утрачивали силу после смены хана на престоле. В любом случае требовалось заключение нового договора, в чем, собственно, и заключалась цель обмена послами.

В Москве отдавали себе отчет в том, что династическая ситуация в Крыму по-прежнему является нестабильной, и правящий хан может быть смещен с престола Портой, либо свергнут с престола мятежной знатью. Наконец, хан мог просто-напросто умереть. В «наказных памятях» посольствам А. Лодыженского и князя Г.К. Волконского - П. Овдокимова содержались традиционные инструкции на этот счет («а нечто учиниться на Крыме новой царь»): установление контактов с новым правителем с учетом устойчивости его положения на престоле ${ }^{10}[16$, с. 41-42]. Опасения руководителей московской дипломатии имели серьезные основания: в Посольском приказе было известно, что хан Джанибек-Гирей имеет опасных противников: братьев Мухаммед-Гирея и Шагин-Гирея - сыновей некогда признанного Москвой в качестве хана СеадетГиря II. Особенно опасен был Шагин-Гирей.

Центральной проблемой русско-крымских «ссылок», как известно, являлся вопрос о выплате так называемых «поминок» - добровольных посольских даров, «запросных денег» и «жалования» крымской знати. Размер «поминок» никогда не вносился в тексты русско-крымских «докончаний» и определялся по факту последних крупных выплат, как правило, привозимых посольством при заключении «докончания». Количество «запросных денег» (десять тысяч рублей) было согласовано в устной форме во время переговоров Ямгурчея аталыка в Москве в 1593 году. При этом в Москве исходили из того, что это будет «разовая выплата», а в Крыму трактовали это как обязательство «выплат» при каждом посольском размене. Кроме того, с 1593 г. посольский размен сопровождался посольским съездом, где «разменный посол» - Ахмед-паша Яшлавский - «князь Сулешев» и представители крымской знати заключали предварительное мирное соглашение - приносили шерть. Это сопровождалось выплатой им со стороны московских «разменных послов» так называемого «разменного жалования».

24 октября 1613 г. в Крым было отправлено посольство Амброзия Лодыженского и подьячего Петра Данилова. В мае 1614 г. П. Данилов вернулся в Москву вместе с крымскими гонцами во главе с Алеем-мурзой [11, c. 273]. Последний имел ранг фактического посланника. Ханские послания, доставленные Алеем-мурзой, не сохранились. Однако их содержание отображено в «наказной памяти» посольству князя Г.К. Волконского и П. Овдокимова. Джанибек-Гирей сообщал о готовности принести шерть перед новыми московскими послами при условии выплат «поминок» и «запросных денег».

П. Данилов сообщил об успешном исполнении посольства. К сожалению, представленный им «статейный список» также не сохранился. «Статейный список», доставленный в августе 1614 г. вернувшимся А. Лодыженским, охватывает события мая - июня 1614 года.

Целью посольства Амброзия Лодыженского и Петра Данилова было определение возможностей заключения нового договора, направленного против Речи Посполитой. При этом в данной ему «наказной памяти» приводились многочисленные отсылки ко временам «дружбы и братства между Москвой и Крымом «при царе Борисе». Напоминалось и о том, что «Казы Гирей царь шертовал на куране» на договоре с Москвой [16, с. 31]. Подчеркивалось, что предшественник Джанибек-Гирея 
на бахчисарайском престоле хан СеламетГирей «к царю Василию в своих грамотах писал и з гонцы своими приказывал, с крепким обещанием, хотячи бытии по прежнему с ним со всем Московским государством в крепкой дружбе и любви, другом другом бытии, а недругу недругом бытии» [16, с. 31-32]. Переговоры Лодыженского показали, что хан Джанибек-Гирей и значительная часть его «ближних людей», прежде всего клан беков Яшлавских - «князей Сулешевых», позитивно относятся к заключению договора. Однако главным условием «докончания» являлись выплаты «поминок» и «запросных денег», по крайней мере в количестве отправленных в 1594 г. с посольством князя М.А. Щербатова и дьяка А. Демьянова, которое заключило «докончание» с ханом Гази-Гиреем II. Была достигнута принципиальная договоренность о проведении посольского съезда и размена. Это было объявлено А. Лодыженскому ханом Джанибек-Гиреем на отпускной аудиенции в Перекопе 30 мая 1614 года. «Для посольской розмены, для договору добрых дел» А. Лодыженского и крымское посольство к московскому царю должен был сопровождать Axмед-паша - «князь Сулешев» [16, с. 54-55].

Переговорам о заключении нового договора с Крымом в 1614-1615 гг., как и в 1593 г., и в 1602 г., предшествовало заключение «предварительного договора» на посольском съезде, одновременно с разменом направлявшимся в Крым московского посольства с новым крымским посольством, двигавшимся в Москву. Посольские съезды и размены проводились летом 1582 г. под Путивлем, осенью 1593 г. под Ливнами, затем весной 1602 г. под Царевым-Борисовым. При этом тогда посольский съезд первоначально также предполагалось провести под Ливнами, но ввиду задержки прибытия крымского посольства его было решено провести под Царевом-Борисовым. С обеих сторон назначались «разменные послы», которые должны были провести переговоры перед непосредственно посольским разменом. С московской стороны в организации посольских съездов и разменов 1593 и 1602 гг. принимали участие такие опытные дипломаты, как Б.Я. Бельский и видные представители государева двора, как боярин князь Ф.И. Хворостинин и окольничий И.М. Бутурлин.
В Крыму организация и проведение посольских съездов была прерогативой клана Яшлавских - «князей Сулешовых». Глава клана Ахмед-паша Яшлавский - «князь Сулешев» проводил посольские съезды в 1593 и 1602 годах. Эти традиции проведения посольских съездов и разменов, восходящие к 90-м гг. XVI в., естественно, использовала московская дипломатическая служба. Вопрос о проведении посольского съезда и размена должен был быть поставлен в Крыму еще гонцом В. Пургасовым. В послании царю Михаилу Федоровичу, доставленном в июне 1613 г. в Москву гонцом Аллаш Богатыром, хан Джанибек-Гирей согласился на проведение посольского съезда и размена. Переговоры об организации и сроках посольского съезда и размена провели А. Лодыженский и П. Данилов. Съезд и размен предполагалось провести, как и в 1593 г., под Ливнами, что было инициативой московской стороны. Место проведения определялось разорением Царева-Борисова, о чем было указано в «наказной памяти» А. Лодыженскому [16, с. 28].

Предложение хана Джанибек-Гирея, поддержанное его «ближними людьми», провести посольский съезд и размен под Валуйками на реке Оскол А. Лодыженскому удалось отклонить. В Москве исходили из того, что организация посольского съезда - размена - была возложена на Ахмед-пашу Яшлавского - «Сулешева», по-прежнему являвшегося ведущим «ближним человеком» уже третьего после Гази-Гирея II и Селамет-Гирея крымского хана Джанибек-Гирея. Это в значительной степени определяло, помимо чисто военных соображений, место проведения посольского съезда и размена: Ахмед-паше осенью 1593 г. под Ливнами сопутствовал успех.

Съезд и размен совершились относительно быстро, в то время как в 1601-1602 гг. посольский съезд - размен носил затяжной характер. С августа до октября 1601 г. посольство князя Г.К. Волконского и дьяка П. Огаркова вместе с «разменными послами» во главе с И.М. Бутурлиным находилось у Ливен. В ноябре 1601 г. ввиду задержки прибытия крымского посольства все послы по указанию из Москвы прибыли в Царев-Борисов. Посольский съезд и размен было решено по согласованию с крымской стороной провести на 
реке Оскол недалеко от крепости. А.А. Новосельский высказал мнение, что посольство князя Г.К. Волконского и дьяка М. Огаркова находилось у Царева-Борисова несколько месяцев [14, с. 47]. Это подтверждается статейным списком разменных послов И.М. Бутурлина. Из него следует, что посольский съезд и размен состоялся только в конце апреля начале мая 1602 года ${ }^{11}$. В 1613-1614 гг. московское правительство, учитывая опыт 16011602 гг., сочло необходимым проведение посольского съезда и размена под Ливнами. А. Лодыженскому удалось согласовать место проведения посольского съезда и размена именно под Ливнами, о чем он информировал московские власти с отпущенным весной 1614 г. подьячим Петром Даниловым. 30 мая 1614 г. на отпускной аудиенции А. Лодыженскому хан Джанибек-Гирей подтвердил, что местом посольского съезда и размена будут Ливны [16, с. 55]. А. Лодыженский, выступивший из Крыма вместе с отправленным ханом посольством Мустафы-мурзы и разменным послом Ахмед-пашой Яшлавским, в пути отправлял донесения в Москву со служилыми татарами о следовании к Ливнам [16, с. 4951]. После выступления ханского посольства и А. Лодыженского из Крыма возникли осложнения: Ахмед-паша Яшлавский, опасаясь встречи с совершавшими перманентные нападения на «московские украйны» отрядами ногайских мурз, стал настаивать на проведении посольского съезда и размена «на Волуйки», что ранее предлагалось крымской стороной. После получения грамоты к Axмеду-паше Яшлавскому от разменных послов князя Г.П. Ромодановского «с товарыщи» о том, что они в любом случае не будут двигаться дальше Ливен за реку Сосну, московский «амиат» вернулся к заранее согласованному решению.

Подготовка к отправлению посольства в Крым началась в мае 1614 г. и продолжалась в течение июня месяца.

«Наказная память» посольству князя Г.К. Волконского и дьяка П. Овдокимова во многом дублирует «наказную память», данную посольству А. Лодыженского и П. Данилова. Прежде всего это, по словам А.А. Сергеева, «исторический очерк Смуты» - подробное изложение событий от ее начала до из- брания на царство Михаила Федоровича. Далее подчеркивались успехи «его царского величества воевод» против «польских и литовских людей». Дипломатические «ссылки» с Речью Посполитой не конкретизировались; говорилось только об обмене гонцами, о размере пленными людьми. Подчеркивалось, что «ссылки» осуществляются от лица бояр ввиду непризнания польско-литовской стороной избрания Михаила Федоровича [16, с. 35]. На первый взгляд подробно, но в действительности весьма обтекаемо говорилось о состоянии отношений со Шведской короной: новый король Густав Адольф прислал гонца с целью выдачи опасных грамот для шведского посольства. Ответ на возможный вопрос об оккупации шведами Новгорода Великого давался в обеих «наказных памятях» однозначно: «Новгородское государство к Московскому государству по-прежнему, и немецкие люди, чаю, уж из Новгорода и изо всей Новгородской земли посяместа уже и вышли» ${ }^{12}[16$, с. 37$]$. Описывался поход воеводы князя И.Н. Одоевского против И. Заруцкого и занятие царскими войсками Астрахани ${ }^{13}$.

Значительная часть «наказной памяти» содержала инструкции относительно порядка заключения русско-крымского «докончания». Посольство князя Г.К. Волконского и дьяка П. Овдокимова повезло не два противня «докончания» («шертную грамоту» и «государево слово»), ограничившись только «списком на образец», «какой бытии шертной записи», на которой «шерть дати Джанибек-Гиреюцарю» и указанием, что «государево слово» должно представлять собой «грамоту, списанную против того списка» с перемещением «имени государева перед царевом» ${ }^{14}$.

Два противня договора должны были быть изготовлены в Крыму, что в известной степени отражало отход от «прежних обычаев» со стороны Москвы. Основные положения составленного в Посольском приказе проекта договора содержали традиционные формулировки московско-крымских «докончаний» XVI века. Главными из них являлись отказ крымской стороны от нападений «на государевы земли», распространявшийся и на «Арсланаев улус», и взаимные обязательства сторон по отношению к общим «недругам»«другом другом бытии, а недругу недругом 


\section{ИСТОРИЯ СМУТНОГО ВРЕМЕНИ}

бытии». Для проведения посольского съезда и размена были назначены «разменные послы»: окольничий князь Григорий Петрович Ромодановский, князь Афанасий Федорович Гагарин и подьячий Семен Самсонов.

Из «разменных» послов определенный политический вес в Москве имел только князь Григорий Петрович Ромодановский, пожалованный в окольничьи при царе Василии Шуйском, затем был «при Литве» боярин, с 1613 г. вновь «разжалованный в окольничьи». Свою миссию князь Григорий Петрович явно рассматривал как важный шаг к укреплению своего влияния при дворе царя Михаила Федоровича. Не случайно в дальнейшем он использовал свое участие в посольском съезде и размене под Ливнами как повод для местнического спора с князем Юрием Яншеевичем Сулешевым. племянником Ахмед-паши Яшлавского [5, с. 478].

Посольство Г.К. Волконского и П. Овдокимова вместе с разменными послами и отпускаемыми крымскими гонцами выступило из Москвы 16 июля 1614 года ${ }^{15}$. Значение, которое придавалось в Москве этому событию, выразилось в записи об отправлении «на розмену на Ливны» князя Г.П. Ромодановского и князя Ф.Ф. Гагарина вместе с посольством князя Г.К. Волконского и дьяка П. Овдокимова [5, с. 142]. 20 июля посольство прибыло в Серпухов и в тот же день выступило в Новосиль. Из Новосили послы 29 июля двинулись к Ливнам, куда прибыли 3 августа. На полпути от Новосили к Ливнам 1 августа послов встретил отпущенный ранее прибывшими к реке Сосне крымцами А. Лодыженский, который двинулся вместе с ними обратно к Ливнам ${ }^{16}$.

Посольский съезд и размен состоялись 5-7 августа 1614 г. под Ливнами и благодаря «прямой преемственности» с крымской стороны во многом напомнили съезд и размен 1593 года. Как и в 1593 г., Ахмед-паша вел препирательства о месте переговоров, которые также в конечном итоге состоялись (5 августа) на мосту через Сосну, а затем «на московской стороне реки ${ }^{17}$. Шерть Ахмед-паша вновь приносил в шатрах, установленных русскими послами «на своей стороне» у моста. «Шертная запись» Ахмед-паши в составе русской посольской документации сохрани- лась в составе «отписок» послов князя Г.К. Волконского и дьяка П. Овдокимова и в составе данной им «наказной памяти» ${ }^{18}$. Запись была опубликована Ф.Ф. Лашковым [9, c. 11-12]. В донесении послов было отмечено, что шерть о Ахмед-паша дал «как при розмене при князе Михаиле Хворостинине» ${ }^{19}$. Ахмед-паше и другим мурзам вручили «разменное жалование», после чего был пир ${ }^{20}$. В отличие от 1593 г. (как и в 1602 г.) главу рода Яшлавских не сопровождали представители других кланов крымской знати. Присутствовали только Яшлавские-«Сулешевы» -многочисленные сыновья и племянники Ахмедпаши. Вторым разменным послом с крымской стороны был его брат Ибрагим-паша-мурза, по иронии истории отпущенный из русского плена и переданный своему брату на тех же берегах реки Сосны в 1593 году. Посольский размен вновь состоялся на следующий день (6 августа) после принесения Ахмед-пашой шерти ${ }^{21}$. В Москву отправилось посольство Мустафы-мурзы, в Крым - посольство князя Г.К. Волконского и дьяка П. Овдокимова. В Крым также возвращался посланник Алей-мурза. Еще один день (7 августа) продолжались препирательства относительно количества «разменного жалования».

После завершения посольского съезда и размена посольство двинулось в Крым. До реки Оскола послы шли три дня, у Оскола стояли два дня и за четыре дня добрались до крепости Волуек. В Волуйках послы задержались два дня. В свои улусы возвращались Большие ногаи с очередного набега. 25 августа послы с большими предосторожностями «перелезли» реку Донец. 29 августа послы «пришли в ногаи», вступив на территорию улуса Мансуров («Арсланаева улуса»), часть которого в это время контролировалась Кан-Темир-мурзой ${ }^{22}$. На первом же «стану» Ахмедпаша известил послов, что хан Джанибек-Гирей получил приказ Порты «не мешкая идти на литовского короля». Со слов Ахмед-паши предполагалась серьезная кампания: сосредоточивалась армия численностью в «восемьдесят тысяч ратных людей», из которых «двенадцать тысяч янычар с вогненным боем» были «с восьмидесятью орудиеми». Сам хан находился у Перекопа, где ожидал послов. Через два дня посольский караван достиг реки 
Миуса, где «на стану» к послам прибыл князь Александр Урусов, кочевавший там «со своим юртом». Князь Александр Арасланович подтвердил сведения о сосредоточении крымской орды у Перекопа, куда уже хан «призвал» Богатыр-Гирея «князя Дивеева». Сам Александр также готов был туда отправиться. Кроме того, Александр Урусов сообщил, что его брат князь Петр только что прибыл к Перекопу из Белгорода (Аккерамана), куда был послан ханом для связи с османским командованием, и привез приказ выступать «не мешкая» ${ }^{23}$.

Между тем послы везли датированную июлем 1614 г. грамоту царя Михаила Федоровича князю Петру Араслановичу Урусову, в которой содержался призыв вернуться в Москву, где он будет «пожалован по своему отечеству» и «даже свыше прежнего» ${ }^{24}$. Неясно, однако, дошла ли грамота до адресата, так как с самим князем послы так и не встретились.

Послы двинулись к Перекопу, куда прибыли 9 сентября.

Пребывание посольства князя Г.К. Волконского и П. Овдокимова в Крыму продолжалось с сентября 1614 г. по июнь 1615 года. Первое время послы пребывали за Перекопом вблизи полевой ставки Джанибек-Гирея. Затем последовал период неопределенности, связанный с отсутствием хана в Крыму, когда послы пребывали в Яшловском предместье Бахчисарая (осень 1614 г. - весна 1615 г.). Наконец, последовал заключительный период переговоров и отпуска (апрель - июнь 1615 г.).

Переговоры послов о заключении договора шли исключительно сложно и напряженно. На аудиенции у хана 11 сентября 1614 г. послы вручили хану «шертную запись». Джанибек-Гирей принес шерть, однако заявил, что она будет иметь силу только в случае присылки затребованных «запросных денег», «поминок» и «жалования крымской знати». Послов насторожило, что представленный им документ не был зачитан. Шертовал хан один. Калга, нураддин, «царевичи»-султаны и «ближние царевы люди» к шерти не приводились. Князь Г.К. Волконский заявил, что он приводил к шерти хана Гази-Гирея II только с «ближними людьми». После протеста послов «ближние люди» были приведены к шерти.
Текст «шертной записи» был зачитан. Послам было заявлено, что «шертная грамота», переписанный текст крымского противня, будет вручена им только после возвращения хана из похода на Речь Посполитую ${ }^{25}$. В дальнейшем послы несколько раз требовали предоставления им «шертной грамоты». Ахмед-паша вел тонкую игру. Он дважды привозил «шертную грамоту». Первый раз послы ее отвергли изза умаления титула царя Михаила Федоровича. В нем отсутствовало слово «самодержец». Ахмед-паша отвез документ обратно, но спустя некоторое время заявил, что его «потеряли» ${ }^{26}$. После длительных препирательств с послами «шертная грамота» была «переписана» и вручена второй раз 27.

В текст «шертной грамоты» на этот раз было «вписано» обязательство присылки десяти тысяч запросных денег при каждом посольском размене. Послы выразили протест, заявив, что при принесении шерти ханом этот вопрос не обсуждался и в очередной раз вручили обратно «шертную грамоту» Ахмед-паше ${ }^{28}$.

Третий раз Ахмед-паша вручил «шертную грамоту» уже в январе 1615 года. Там отсутствовало обязательство выплат десяти тысяч запросных денег, но по-прежнему Михаил Федорович не именовался «самодержцем». Послы на этот раз вынуждены были взять «шертную грамоту», но обратились с протестом к другим «ближним царевым людям» ${ }^{29}$.

Однако перипетии с «шертной грамотой» были не случайны: хан отказался от планов похода на Речь Посполиткю и вместо этого пошел «на черкасскую землю».

Послы справедливо заявили, что это является нарушением обязательств хана, принятых на себя им при принесении шерти. Из путанных объяснений Ахмед-паши выяснилось, что главную угрозу для себя хан усматривает в Шагин-Гирее. Не меньшее внимание ханом и его окружением уделялось политике бия Иштерека.

Вскоре послам пришлось столкнуться с «инициативами» «Араслановых детей Урусова» князей Петра и Александра - Урак-мурзы и Зурбек-мурзы: Ахмед-паша Яшлавский передал им их «челобитие», касающееся их отца Джан-Арсалана. Последний после занятия Астрахани был увезен в Москву. Братья упол- 


\section{ИСТОРИЯ СМУТНОГО ВРЕМЕНИ}

номочили Ахмед-пашу Яшлавского просить послов «отписать государю вашему», чтобы Джан-Арслана «отпустили опять в Астрохань». Князья Урусовы предлагали поставить их отца бием Большой Ногайской Орды вместо «князя» Иштерека, который «государю вашему грубен» ${ }^{30}$. Послы ответили, что «не ведают», где находится в настоящее время Джан-Арслан, но обещали сообщить об инициативе его детей по возвращении в Москву.

Послы, вероятно, уже были осведомлены от А. Лодыженского о том, что в Крыму внимательно следят за политическими комбинациями бия Иштерека. Во всяком случае в статейном списке А. Лодыженского есть информация о контактах Иштерека с османскими чавушами в период его «союза» с И. Заруцким весной 1614 г., о которых послу стало известно при следовании из Крыма к Ливнам $[16$, с. 56$]$.

Ахмед-паша согласился на передачу «челобития» братьев Урусовых. Просматривалось намерение хана Джанибек-Гирея усилить свое влияние у Больших Ногаев, местом кочевки которых в это время являлось Предкавказье. Хан, вероятно, рассчитывал использовать мурз Большой Ногайской Орды против Шагин-Гирея. Фигура Иштерека, интриговавшего на протяжении последних лет одновременно и с Заруцким, и с Москвой, и с Портой, его явно не устраивала. Но инициатива Урусовых, несомненно, согласованная с ханом, не имела шансов на реализацию: незадолго до этого, в конце 1614 г. и затем в начале 1615 г., Иштерек возобновил шертные обязательства перед Москвой [18, с. 398].

Наконец, в январе 1615 г. ханская «дума» приняла решение об отправлении в поход на Речь Посполитую нураддина Азамат-Гирея с пятнадцатитысячной ордой. В походе должны были участвовать и «мурзы Дивеевы», а также сыновья Ахмед-паши Яшлавского ${ }^{31}$. Поход действительно состоялся. Нураддин выступил из Перекопа 6 января и вернулся в Бахчисарай 7 марта 1615 года. В походе участвовали «Ахмед-пашины дети» и многие мурзы «Дивеевы» во главе с Кан-Темиром. Был приведен большой полон ${ }^{32}$. На следующий день после возвращения Азамат-Гирея 8 марта к послам прибыл Ахмед-паша и, красочно описав успехи Азамат-Гирея, потребо- вал для участвовавших в походе мурз дополнительного «жалования». Послы резонно ответили, что ими «все роздано» ${ }^{33}$. В последующие дни препирательства с Ахмед-пашой продолжились.

Вопрос встал о присылке «разменного жалования» Ахмед-паше и другим представителям клана Яшлавских на посольский размен. Ахмед-паша намерен был сопровождать к месту размена отпущенных послов и новое крымское посольство. Было решено, что посольский размен состоится теперь под Волуйками. Однако послы исходили из того, что, так как предварительное соглашение уже было заключено принесением шерти Ахмедпаши, «разменное жалование» московскому «амиату» и его многочисленным родственникам (сыновьям, брату и племянникам) может быть урезано.

Между тем «время поджимало». 16 апреля к послам прибыл служивый татарин толмач Тимофей Баубеков, доставивший грамоты от имени Михаила Федоровича хану и знати ${ }^{34}$. Списки с этих грамот были вручены послам. Им также были доставлены инструкции. Некоторые инструкции Т. Баубеков, один из опытнейших татарских толмачей Посольского приказа [10, с. 380], сообщил лично. Посольство в Крым было отправлено и приближалось к Волуйкам. Послам следовало ускорить отпускную аудиенцию и рассмотреть вопрос об организации посольского размена.

Однако ситуация складывалась неоднозначно. Аудиенцию послов у хана, на которой служилый татарин должен был вручить доставленные грамоты, «заблокировал» Ахмедпаша. Он потребовал увеличения «запросного жалования» себе и своим родственникам под предлогом гибели своего сына Тин-паши «по дороге из Белгорода в Крым» в результате нападения «черкасов». Послы отказались ${ }^{35}$. К тому же в привезенной Т. Баубековым грамоте царя Михаила Федоровича о выплате ему «разменного жалования» не говорилось. Московский «амиат» пришел в ярость. Настоятельные просьбы послов об аудиенции у хана он отклонял. Напоминание послов о том, что новые московские послы уже двигаются к Волуйкам, не производили на него никакого впечатления ${ }^{36}$. 
18 апреля Ахмед-паша вызвал послов в Бахчисарай и сообщил им о том, что царь хочет «думать со своими ближними людьми бытии послам до отпуску у царя или не быть» ${ }^{37}$. Стало ясно, что хан не желает принимать привезенные Т. Баубековым послания. Вопрос встал и об отпускной аудиенции. Перспектива выпроваживания послов без отпускной аудиенции у хана была неприемлема, так как являлась знаком «порушения доброго дела» - фактическим провалом исполнения посольства. Конечно, послы понимали, что позиция Ахмед-паши отражает в известной степени и колебания хана Джанибек-Гирея, не желавшего принимать на себя определенные обязательства перед Москвой. Наконец, 14 мая Ахмед-паша сообщил послам, что «царь велел бытии им у себя».

Отпускная аудиенция послов у хана Джанибек-Гирея 16 мая 1615 г. выявила несовпадение позиций сторон по ключевым вопросам.

На аудиенции присутствовал цвет крымской знати: Яшлавские, «Куликовы», «Дивеевы». В начале аудиенции кн. Г.К. Волконский вручил хану доставленную Т. Баубековым грамоту царя Михаила Федоровича и произнес «речь», которая кратко излагала ее содержание. Московский царь изъявлял радость по поводу принесения шерти ханом, особо подчеркивая, что «шертная грамота» вручена «в руки» его послам. Подчеркивалось, что хан готов «дружить» согласно принесенной шерти «по мусульманскому закону». Выражалась радость, что «утвержденная шертная грамота писана прямым словом» ${ }^{38}$. Москва, таким образом, исходила из того, что договор заключен, и после посольского размена будет введен в действие. Далее князь Г.К. Волконский, напомнив, что «прежние великие государи цари российские с предками вашими прежними царями крымскими были в братской любви и в крепкой дружбе», поведал, что принесенная ханом шерть была следствием договора «учиненного на Ливнах» разменными послами Ахмедпашой Яшлавским и окольничим князем Г.П. Ромодановским ${ }^{39}$. Князь Григорий Константинович напомнил, что он доставил в Крым «запросные деньги» и «большие поминки», «что у нас лучилось», не уточняя их количества ${ }^{40}$.

В заключение Волконский сообщил, что отпущенные в марте крымский посол Муста- фа-мурза «с товарыщи» и посланник Исаак Иванович Спешнев с «поминками и с казною» уже находятся в Волуйках и предложил ускорить движение к Осколу, где должен был состояться посольский размен нового крымского посольства и, соответственно, его отпуск ${ }^{41}$. Далее Петр Овдокимов пространно выразил надежду на совместную борьбу против «общего нашего недруга», упомянув о походе Азамат-Гирея. Он напомнил об обещании хана самому «идти на нашего недруга на польского короля войною» ${ }^{42}$.

Однако Джанибек-Гирей ответил, что сам в поход не пойдет, но «посылает на литовского короля землю» своего брата калгу Девлет-Гирея. Хан потребовал от послов сообщить точное количество «запросных денег» и «поминок», которое должно было доставить посольство И.И. Нестерова, а также количество «нашим ближним людям жалования» ${ }^{43}$. Послы уклонились от прямого ответа, заявив, что «Московское государство разорено».

Джанибек-Гирей потребовал присылки «поминок» и «запросных» денег от нового посольства «прямо в Крым» еще до посольского размена. Послы вполне резонно заявили, что это невозможно ввиду угрозы со стороны «черкасов», ссылаясь также на недостаточное количество «провожатых». Далее встал вопрос о характере проведения «посольского размена» как такового. Ранее Ахмед-паша требовал от имени хана ускорения присылки «поминок и «запросных денег».

Послы выполнили эти условия, но сообщили, что новое посольство не привезло с собой «разменного жалования» Ахмед-паше и представителям рода Яшлавских ввиду отказа Ахмед-паши от проведения полноценного посольского съезда и размена. Ахмед-паша пришел в ярость, заявив, что в таком случае он вообще не поедет «встречать» новое посольство. Тогда Волконский и Овдокимов обстоятельно объяснили, что сама крымская сторона настаивала на скорейшей присылке «запросных денег» и «поминок», поэтому вместо посольского размена под Ливнами на Сосне он будет проводиться под Валуйками на Осколе. Валуйки - это крайний «укрепленный город» по отношению к крымским улусам, и посольство уже находится там. В случае если Ахмед-паша откажется с «провожатыми»- 
военным контингентом - ехать к Волуйкам, московских «провожатых» будет недостаточно. Послы заявили, что из Валуек были отозваны многие люди для встречи следовавшего из Азова османского эмиссара Алей чавуша ${ }^{44}$. Это соответствовало действительности: эмиссар Порты следовал в Москву, хотя до нее не доехал, скончавшись в пути $[17$, с. 6$]$. Но упоминание о «ссылках» Москвы с Портой не возымело ожидаемого эффекта.

Конфликтная ситуация нарастала и хан предложил гонцами отправить вновь прибывшего служилого татарина вместе со своим гонцом в Москву для информации о сложившийся ситуации с тем, чтобы прислать усиленное количество «провожатых» вместе с «запросным жалованием». Послы резонно возразили, что сама крымская сторона требовала ускоренной присылки «поминок», «запросных денег» и «жалования» крымской знати как главного условия организации похода «на литовского короля». Они также напомнили, что Московское государство находится в состоянии войны с Речью Посполитой и лишних людей «у государя нашего нет». Прибытие посольства в этом случае затянется на несколько месяцев. Наконец хан приказал Ахмед-паше сопровождать послов к Валуйкам и произвести там посольский размен ${ }^{45}$.

После аудиенции Ахмед-паша во главе внушительной группы крымской знати, включавшей в себя и Богатыр-Гирея «Дивеева», заявил, что вопрос о присылке «разменного жалования» является принципиальным. Агрессивность Богатыр-Гирея имела прямо противоположные последствия. Встретившись в Валуйках с послами И. Спешневым и Б. Нестеровым на обратном пути, Волконский и Овдокимов порекомендовали урезать количество предназначенного ему «жалования».

Молчание хана Джанибек-Гирея на отпускной аудиенции послам относительно принесенной им шерти было не случайно. Уже после выступления посольства из Крыма выяснилось, что «шертная грамота», врученная в январе послам, фактически дезавуирована. В Москву с посольством Булат-улана отправлялась «посыльная шертная грамота». Это было послание хана царю Михаилу Федоровичу, содержащее требования присылки «поминок» и «запросных денег», не имевшее ни- чего общего с «шертной записью», ранее врученной послам [9, с. 12-15]. Это было предварительное соглашение, ввод в действие которого обусловливался присылкой «поминок» и «запросных денег», сумма которых определялась в десять тысяч рублей при каждом посольском размене. В конце содержалось «пожелание» составить в Москве новую «шертную грамоту», куда были внесены крымские требования - «и делати бы по нашей шерти так же». Правда, в документе содержались традиционные формулировки русско-крымских окончаний. Документ не был запечатан «золотой печатью».

Таким образом, речь не шла о заключении «докончания». Не случайно А.А. Новосельский, излагая содержание хода переговоров посольства князя Г.К. Волконского и П. Евдокимова, не указывает, что оно добилось заключения «формального договора о мире и дружбы», что являлось его целью $[14$, с. $83-$ 84]. Д.В. Лисейцев, не вдаваясь в детали, констатирует, что «хан Джанибек-Гирей принес шерть царю Михаилу Федоровичу [11, с. 274].

Договорный акт 1614 г. из «шертной грамоты», составленной на основе присланного с послами текста «шертной записи», превратился к лету 1615 г. в документ, представлявший собой односторонние обязательства хана Джанибек-Гирея воздерживаться от нападений на Русское государство при условии выплат «поминок» и «запросных денег». Подобная практика крымской стороны при заключении договорных актов была хорошо известна в Москве с XVI века. В дальнейшем договор 1614 г. даже в «урезанном виде» не был введен в действие, хотя и оказал определенное влияние на стабилизацию тяжелейшего внешнеполитического положения Русского государства на завершающем этапе военного противостояния с Речью Посполитой в 1617-1618 годах.

В июне 1615 г. посольство князя Г.К. Волконского и дьяка П. Овдокимова было, наконец, отпущено. Послы 30 июня перешли Донец и вскоре прибыли к Валуйкам, где во второй половине июля был произведен посольский размен: они двинулись в Москву вместе с новым крымским послом Булат-уланом, а в Крым двинулось посольство И.И. Спешнева и Б. Нестерова вместе с отпущенным послом 
Мустафой-мурзой. Затягивание размена было вызвано конфликтом с Ахмед-пашой.

Под Валуйками Ахмед-паша вел себя крайне агрессивно, заявив, что не будет производить размен без присылки к нему «разменного жалования». В результате пребывание отпущенного посольства затянулось на несколько недель ${ }^{46}$. Следует отметить, что посольство И.И. Спешнева и Б. Нестерова вместе с отпускаемыми крымскими дипломатами все это время пребывало в Валуйках.

Московская дипломатия проявила неуступчивость в вопросе о присылке «запросного жалования». По меткому замечанию А.А. Новосельского, анализировавшего ход посольского размена в июле 1615 г., «задачей Москвы было дать как можно меньше, задачей крымцев, наоборот, вырвать как можно больше» $[14$, с. 84$]$.

Материальные претензии хана, представителей династии Гиреев и крымской знати, особенно ярко проявившиеся при отпуске посольства Волконского - Овдокимова, безусловно, сыграли негативную роль в реализации главной цели московской дипломатии: достижение полноценного союза с Крымом.

Результаты. Таким образом, посольство князя Г.К. Волконского и дьяка П. Овдокимова не смогло выполнить в полном объеме свою главную задачу: заключение полноценного военного союза с Крымским ханством.

Тем не менее московская дипломатия могла теперь использовать само принесение шерти ханом на тексте «договорной записи», трактуя его как заключение полноценного договоpa, что и было предпринято во время посольского съезда с комиссарами Речи Посполитой под Смоленском. Переговоры под Смоленском в ноябре - декабре 1615 г. проходили уже после похода хана Джанибек-Гирея на Галицию, Подолию и Львовщину (август и сентябрь 1615 г.). В Посольском приказе полагали, что у польсколитовской стороны должно сложиться представление о том, что союз Москвы и Бахчисарая стал реальностью. На это были ориентированы инструкции послам, отправляемые из Посольского приказа, предписывавшие им сообщать о успешном походе хана ${ }^{47}$. Однако слабый состав московской делегации на переговорах, вероятно, не позволил в полной мере разыграть «крымскую карту». Тем не менее польско-литовская сторона, взявшая после провала посольского съезда под Смоленском курс на возобновление войны с Москвой, по крайней мере до лета 1616 г., учитывала возможность новых крымских нападений на свою территорию. Ситуация изменилась с вступлением Порты в войну с Сефевидским Ираном, в которую был вовлечен Крым, что привело к ослаблению крымского натиска на Речь Посполитую. Это, в свою очередь, привело к активизации подготовки похода «королевича» Владислава на Россию.

\section{ПРИМЕЧАНИЯ}

${ }^{1}$ РГАДА. Ф. 123. Оп. 1. 1613 г. Ед. хр. 1.

${ }^{2}$ Там же. 1614 г. Ед. хр. 1.

${ }^{3}$ Там же. Ед. хр. 2.

${ }^{4}$ Там же. Ед. хр. 3, 4.

${ }^{5}$ Там же. Ед. хр. 5.

${ }^{6}$ РГАДА. Ф. 123. Оп. 2. Ед. хр. 33, 34.

${ }^{7}$ РГАДА. Ф. 123. Оп. 1.1614 г. Ед. хр. 2. Л. 149.

${ }^{8}$ Там же. Ед. хр. 3. Л. 14.

${ }^{9}$ Там же. Ед. хр. 2. Л. 150.

${ }^{10}$ Там же. Ед. хр. 3. Л. 143-145.

${ }^{11}$ РГАДА. Ф. 123. Оп. 1. 1601 г. Ед. хр. 2. Л. 102-121.

12 РГАДА. Ф. 123. Оп. 1.1614 г. Ед. хр. 2. Л. 122-129.

${ }^{13}$ Там же. Л. 146-149.

${ }^{14}$ Там же. Л. 262-267.

${ }^{15}$ Там же. Ед. хр. 1. Л. 47.

${ }^{16}$ Там же. Л. 47-49, 53.

${ }^{17}$ Там же. Л. 25-26, 56-74.

${ }^{18}$ См.: РГАДА. Ф. 123. Оп. 1.1614 г. Ед. хр. 1.

Л. 91-94 ; Ед. хр. 2. Л. 262-267.

${ }^{19}$ РГАДА. Ф. 123. Оп. 1. 1614 г. Ед. хр. 1. Л. 94.

${ }^{20}$ Там же. Л. 26-37, 75-96.

${ }^{21}$ Там же. Л. 97.

${ }^{22}$ Там же. Ед. хр. 4. Л. 9.

${ }^{23}$ Там же. Л. 11.

${ }^{24}$ Там же. Ед. хр. 2. Л. 24-25.

${ }^{25}$ Там же. Ед. хр. 4. Л. 41.

${ }^{26}$ Там же. Л. 71.

${ }^{27}$ Там же. Л. 88.

${ }^{28}$ Там же. Л. 88-89.

${ }^{29}$ Там же. Л. 93-94.

${ }^{30}$ Там же. Л. 84-85.

${ }^{31}$ Там же. Л. 82.

${ }^{32}$ Там же. Л. 94-95.

${ }^{33}$ Там же. Л. 95-96.

${ }^{34}$ Там же. Л. 112. 
35 Там же. Л. 114-115.

36 Там же. Л. 117-118.

37 Там же. Л. 118.

${ }^{38}$ Там же. Л. 122.

${ }^{39}$ Там же. Л. 122-123.

40 Там же. Л. 123.

${ }^{41}$ См.: РГАДА. Ф. 123. ОП. 1.1614 г. Ед. хр. 3.

Л. 20-21 ; Ед. хр. 4. Л. 123-124.

42 РГАДА. Ф. 123. ОП. 1. 1614 г. Ед. хр. 4.

Л. 124-125.

43 Там же. Л. 125

44 Там же. Л. 129

${ }^{45}$ Там же. Л. 131-135.

46 Там же. Ед. хр. 3. Л. 3-12.

${ }^{47}$ РГАДА. Ф. 79. Оп. 1. Ед. хр. 30. Л. 427 об.438, 669-669 об.

\section{СПИСОК ЛИТЕРАТУРЫ}

1. Беляков, А. В. Крымские выходцы в России: служба и правовой статус / А. В. Беляков // Золотоордынское обозрение. - 2016. - № 1. C. 137-157.

2. Виноградов, А. В. Род Сулеша во внешней политике Крымского ханства второй половины XVI в. / А. В. Виноградов // Тюркологический сборник: 2005: Тюркские народы России и Великой степи. - М. : Восточная литература, 2007. - С. 26-73.

3. Виноградов, А. В. Состав политической элиты Крымского ханства в 1560-1590-х гг. по материалам русской и польско-литовской посольской документации / А. В. Виноградов // Восток (ORIENS). 2016. - № 5. - C. 25-41.

4. Виноградов, А. В. К вопросу о месте «Смуты» в военно-дипломатической конфронтации Русского государства и Речи Посполитой на рубеже XVI-XVII столетий / А. В. Виноградов // Смутное время: итоги и уроки : материалы III Bсерос. науч. конф. - Иваново : Издатель Ольга Епишева, 2016. С. $40-69$.

5. Дворцовые разряды : в 5 т. Т. 1. 1612-1628. СПб. : Тип. ІІ отд-ния Собственной Его Императорского Величества Канцелярии, 1850. - 656 с.

6. Зайцев, И. В. Политическая история Крымского ханства в XVI-XVII вв. / И. В. Зайцев // История Крыма. - М. : Фонд «Связь эпох», 2017. - Т. 1.C. $392-405$.

7. Кобзарева, Е. И. Смута. Иностранные интервенции и их последствия (конец XVI - первая половина XVII в.) / Е. И. Кобзарева // История внешней политики России. Конец XV - XVII в. - М. : Международные отношения, 1999. - С.195-246.

8. Курбатов, О. А. Военная история русской Смуты начала XVII века / О. А. Курбатов. - М. : Квадрига, 2014. - 240 с.
9. Лашков, Ф. Ф. Памятники дипломатических сношений Крымского ханства с Московским государством в XVI и XVII вв., хранящиеся в Московском Главном Архиве Министерства Иностранных Дел / Ф. Ф. Лашков // Известия Таврической ученой архивной комиссии. - Симферополь, 1890. T. X. - C. 11-15.

10. Лисейцев, Д. В. Посольский приказ в эпоху Смуты / Д. В. Лисейцев. - М. : Ин-т российской истории РАН, 2003. -485 с.

11. Лисейцев, Д. В. Русско-крымские дипломатические контакты в начале XVII столетия / Д. В. Лисейцев // Тюркологический сборник: 2005. -М. : Восточная литература, 2006. -С. 238-282.

12. Лисейцев, Д. В. Русско-крымские отношения в смутное время / Д. В. Лисейцев // История Крыма : в 2 т. - М. : Кучково поле, 2017. - Т. 1. C. $422-423$.

13. Лисейцев, Д. В. Северное Причерноморье в период Смуты в России в начале XVII в. / Д. В. Лисейцев // История Новороссии / отв. ред. В. Н. Захаров. - М. : Центр гуманитарных инициатив, 2018. C. 69-77.

14. Новосельский, А. А. Борьба Московского государства с татарами в первой половине XVII в. / А. А. Новосельский. - М. ; Л. : Изд-во АН CCCP, 1948. $-447 \mathrm{c}$.

15. Сергеев, А. А. Посольство Амвросия Лодыженского и подьячего Петра Данилова в Крым в 1613 году : (К 300-летнему юбилею Царствующего Дома Романовых) / А. А. Сергеев // Известия Таврической ученой архивной комиссии. - Симферополь : Тип. Таврического Губернского Земства, 1913. - T. 50. - C. 7-19.

16. Сергеев, А. А. Наказ, данный отправленным в Крым посланникам Амбросию Лодыженскому и подьячему Петру Данилову, с объявлением об избрании на Российское царство государя Михаила Федоровича. С отписками их и статейным списком бытности их в Крыму / А. А. Сергеев // Известия Таврической ученой архивной комиссии. - Симферополь : Тип. Таврического Губернского Земства, 1913. - Т. 50. - С. 20-56.

17. Смирнов, Н. А. Россия и Турция в XVIXVII вв. : в 2 т. / Н. А. Смирнов. - М. ; Л. : Изд-во МГУ, 1946. - Т. 2. - 174 с.

18. Трепавлов, В. В. История Ногайской Орды / В. В. Трепавлов. - М. : Восточная литература, 2001. $-752 \mathrm{c}$.

19. Трепавлов, В. В. Российские княжеские роды ногайского происхождения (генеалогические истоки и ранняя история) / В. В. Трепавлов // Тюркологический сборник: 2002. - М. : Восточная литература, 2003. - С. 320-353.

20. Флоря, Б. Н. Османская империя, Крым и страны Восточной Европы в конце XVI - начале 
XVII в. / Б. Н. Флоря // Османская империя и страны Центральной, Восточной и Юго-Восточной Европы в XVII в. Ч. 1. - М. : Памятники исторической мысли, 1998. - С. 49-65.

\section{REFERENCES}

1. Belyakov A.V. Krymskie vykhodtsy v Rossii: sluzhba i pravovoy status [The Crimean Descendants in Russia: Service and Legal Status]. Zolotoordynskoe obozreniye, 2016, no. 1, pp. 137-157.

2. Vinogradov A.V. Rod Sulesha vo vneshney politike Krymskogo khanstva vtoroy poloviny XVI v. [The Sulesh Family in the Foreign Policy of the the Crimean Khanate in the Second Half of the $16^{\text {th }} \mathrm{c}$.]. Tyurkologicheskiy sbornik: 2005: Tyurkskie narody Rossii i Velikoy stepi [Turkological Collection: 2005: Turkic Peoples of Russia and the Great Steppe]. Moscow, Vostochnaya literatura Publ., 2007, pp. 26-73.

3. Vinogradov A.V. Sostav politicheskoy elity Krymskogo khanstva v 1560-1590-kh gg. po materialam russkoy i polsko-litovskoy posolskoy dokumentatsii [The Composition of the Political Elite of the Crimean Khanate in the 1560's - 1590's Based on the Materials of the Russian and Polish-Lithuanian Embassy Documentation]. Vostok (ORIENS), 2016, no. 5, pp. 25-41.

4. Vinogradov A.V. K voprosu o meste «Smuty» v voyenno-diplomaticheskoy konfrontatsii Russkogo gosudarstva i Rechi Pospolitoy na rubezhe XVI-XVII stoletiy [On the Role of "The Time of Troubles" in the Military and Diplomatic Confrontation of the Russian State and the Polish-Lithuanian Commonwealth at the Turn of the $16^{\text {th }}-17^{\text {th }}$ c.]. Smutnoye vremya: itogi $i$ uroki: materialy III Vseros. nauch. konf. [The Time of Troubles: the Results and Lessons. Materials of the III All-Russian Scientific Conference]. Ivanovo, Izdatel Olga Episheva, 2016, pp. 40-69.

5. Dvortsovye razryady: v 5 t. T. 1. 1612-1628 [Palace Charges. In 5 vols. Vol. 1. 1612-1628]. Saint Petersburg, Tipografiya II otdeleniya Sobstvennoy Ego Imperatorskogo Velichestva Kantselyarii, 1850. 656 p.

6. Zaytsev I.V. Politicheskaya istoriya Krymskogo khanstva v XVI-XVII vv. [Political History of the Crimean Khanate in the $16^{\text {th }}-17^{\text {th }} \mathrm{c}$. $]$. Istoriya Kryma [The History of the Crimea]. Moscow, Fond "Svyaz epokh", 2017, vol. 1, pp. 392-405.

7. Kobzareva E.I. Smuta. Inostrannye interventsii i ikh posledstviya (konets XVI - pervaya polovina XVII v.) [The Time of Troubles. Foreign Intervention and Its Consequences (Late $16^{\text {th }}-$ First Half of the $17^{\text {th }} \mathrm{c}$.]. Istoriya vneshney politiki Rossii. Konets $X V-X V I I v$. [History of Russian Foreign Policy. Late $15^{\text {th }}-17^{\text {th }}$ c. $]$. Moscow, Mezhdunarodnyye otnosheniya Publ., 1999, pp. 195-246.
8. Kurbatov O.A. Voyennaya istoriya russkoy Smuty nachala XVII veka [The Military History of the Russian Time of Troubles in the Early $17^{\text {th }}$ Century]. Moscow, Kvadriga Publ., 2014. 240 p.

9. Lashkov F.F. Pamyatniki diplomaticheskikh snosheniy Krymskogo khanstva s Moskovskim gosudarstvom v XVI i XVII vv., khranyashchiesya v Moskovskom Glavnom Arkhive Ministerstva Inostrannykh Del [Documents of Diplomatic Relations of the Crimean Khanate with the Moscow State in the $16^{\text {th }}-17^{\text {th }} \mathrm{c}$. Stored in the Moscow Main Archive of the Ministry of Foreign Affairs]. Izvestiya Tavricheskoy uchenoy arkhivnoy komissii [News of the Taurida Academic Archive Commission]. Simferopol, 1890, vol. X, pp. 11-15.

10. Liseytsev D.V. Posolskiy prikaz v epokhu Smuty [Ambassadorial Prikaz in the Time of Troubles]. Moscow, Institut rossiyskoy istorii RAN, 2003. 485 p.

11. Liseytsev D.V. Russko-krymskie diplomaticheskie kontakty v nachale XVII stoletiya [Russian-Crimean Diplomatic Contacts in the Early $17^{\text {th }}$ Century]. Tyurkologicheskiy sbornik: 2005 [Turkic Collection: 2005]. Moscow, Vostochnaya literatura Publ., 2006, pp. 238-282.

12. Liseytsev D.V. Russko-krymskie otnosheniya $\mathrm{v}$ smutnoye vremya [Russian-Crimean Relations in the Time of Troubles]. Istoriya Kryma: v 2 t. T. 1 [The History of the Crimea. In 2 vols. Vol. 1]. Moscow, Kuchkovo pole Publ., 2017, pp. 422-423.

13. Liseytsev D.V. Severnoye Prichernomorye $v$ period Smuty v Rossii v nachale XVII v. [Northern Black Sea Coast during the Time of Troubles in Russia in the Early $17^{\text {th }}$ c.]. Zakharov V.N., ed. Istoriya Novorossii [History of Novorossia]. Moscow, Tsentr gumanitarnykh initsiativ Publ., 2018, pp. 69-77.

14. Novoselskiy A.A. Borba Moskovskogo gosudarstva s tatarami $v$ pervoy polovine XVII $v$. [The Struggle of the Muscovite State with the Tatars in the First Half of the $17^{\text {th }}$ century]. Moscow, Leningrad, Izd-vo AN SSSR, 1948. 447 p.

15. Sergeev A.A. Posolstvo Amvrosiya Lodyzhenskogo i podyachego Petra Danilova v Krym v 1613 godu: (K 300-letnemu yubileyu Tsarstvuyushchego Doma Romanovykh) [Ambrose Lodyzhensky and Clerk Petr Danilov's Embassy to the Crimea in 1613 (To the 300th Anniversary of the Reign of the House of Romanov)]. Izvestiya Tavricheskoy uchenoy arkhivnoy komissii [News of the Taurida Academic Archive Commission]. Simferopol, Tipografiya Tavricheskogo Gubernskogo Zemstva, 1913, vol. 50, pp. 7-19.

16. Sergeev A.A. Nakaz, dannyy otpravlennym v Krym poslannikam Ambrosiyu Lodyzhenskomu i podyachemu Petru Danilovu, s obyavleniyem ob izbranii na Rossiyskoye tsarstvo gosudarya Mikhaila Fedorovicha. S otpiskami ikh i stateynym spiskom 
bytnosti ikh v Krymu [The Order Given to Ambassadors Ambrose Lodyzhensky and Clerk Petr Danilov Sent to the Crimea to Announce the Election of Mikhail Fedorovich to the Russian Throne. With Their Letters and Record Lists on Their Stay in the Crimea]. Izvestiya Tavricheskoy uchenoy arkhivnoy komissii [News of the Taurida Academic Archive Commission]. Simferopol, Tipografiya Tavricheskogo Gubernskogo Zemstva, 1913, vol. 50, pp. 20-56.

17. Smirnov N.A. Rossiya i Turtsiya $v$ XVI$X V I I v v .: v 2$ t. T. 2 [Russia and Turkey in the $16^{\text {th }}$ $17^{\text {th }}$ c. In 2 vols. Vol. 2]. Moscow, Leningrad, Izd-vo MGU, 1946. 174p.

18. Trepavlov V.V. Istoriya Nogayskoy Ordy [History of the Nogay Horde]. Moscow, Vostochnaya literatura Publ., 2001. 752 p.
19. Trepavlov V.V. Rossiyskie knyazheskie rody nogayskogo proiskhozhdeniya (genealogicheskie istoki i rannyaya istoriya) [Russian Princely Families of Nogay Origin (Genealogical Sources and Early History)]. Tyurkologicheskiy sbornik: 2002 [Turkological Collection: 2002]. Moscow, Vostochnaya literatura Publ., 2003, pp. 320-353.

20. Florya B.N. Osmanskaya imperiya. Krym i strany Vostochnoy Evropy v kontse XVI - nachale XVII v. [The Ottoman Empire, the Crimea and the Countries of Eastern Europe in the Late $16^{\text {th }}-$ Early $17^{\text {th }}$ c.]. Osmanskaya imperiya $i$ strany Tsentralnoy, Vostochnoy i Yugo-Vostochnoy Evropy v XVII v. Ch. 1 [Ottoman Empire and the Countries of Central, Eastern and South-Eastern Europe in the 17th c. Part 1]. Moscow, Pamyatniki istoricheskoy mysli Publ., 1998, pp. 49-65.

\section{Information about the Author}

Alexander V. Vinogradov, Candidate of Sciences (History), Senior Researcher, Institute of Russian History, RAS, Dmitry Ulyanov St., 19, 117292 Moscow, Russian Federation, avinogradov1957@yandex.ru, https://orcid.org/0000-0002-7241-8671

\section{Информация об авторе}

Александр Вадимович Виноградов, кандидат исторических наук, старший научный сотрудник, Институт российской истории РАН, ул. Дмитрия Ульянова, 19, 117292 г. Москва, Российская Федерация, avinogradov1957@yandex.ru, https://orcid.org/0000-0002-7241-8671 